\title{
Analysis of the influence of test method and properties of steel fiber addition on concrete under the three-point flexural tensile
}

\author{
Análisis de la influencia del método de prueba y las propiedades de la adición \\ de fibra de acero sobre el concreto bajo la tracción por flexión de tres puntos
}

\author{
Marco Antonio Barbosa de Oliveira ${ }^{1 *} \quad$ Rodrigo Rodrigues da Cunha ${ }^{1}$ \\ Marcelo de Souza Picanço ${ }^{2}$ Dênio Ramam Carvalho de Oliveira ${ }^{2}$ \\ Edson Marcos Leal Soares Ramos ${ }^{2} \quad$ Mike Pereira da Silva $^{3}$
}

Recibido 13 de agosto de 2018, aceptado 25 de marzo de 2019

Received: August 13, 2018 Accepted: March 25, 2019

\begin{abstract}
The characterization of steel fiber reinforced concrete with dry consistency require greater inspection the account of the particularities in the process of mixing, molding and densification, thus this paper aims to propose a methodology combined of densification by manual and mechanical means and the mechanical characterization by the three-point flexural testin prismatic dry cast steel fiber-reinforced concrete specimen. In a qualitative way, the densification-combined methodology provided a smooth surface on the specimen appearance and a reduction of voids due to trapped air. In the flexural test we verified slip-softening and slip-hardening, respectively, to lower and higher reinforcement indexes and theoretical volumes. By the analysis of variance of the results and the database we found out that there was no significant statistical difference to the analyzed residual strength for the combination of the test method (RILEM), consistency (plastic), type (hooked end) and form (glued), when the comparison is made by quadruple association.
\end{abstract}

Keywords: Dry consistency, residual strength, analysis of variance.

\section{RESUMEN}

La caracterización del concreto de consistencia seca con fibras de acero requiere mayores investigaciones por cuenta de las particularidades en el proceso de mezcla, moldeado y adensamiento, por lo tanto, el objetivo de este trabajo es proponer una metodología combinada para la densificación manual y mecánica y la caracterización mecánica con ensayo de tracción en una flexión en tres puntos en de cuerpos de prueba prismáticos de concreto de concreto de consistencia seca con fibras de acero. De modo cualitativo una metodología combinada de densificación proporcionó un aspecto liso a la superficie en el cuerpo de prueba y reducción de los vacíos por el aire aprisionado. En el ensayo de tracción una flexión verificó el comportamiento de slip-softening y slip-hardening, respectivamente, para menores y mayores índices de refuerzo y volúmenes teóricos. Al final se constató que el análisis de varianza del banco de datos indicó mayores valores de resistencia residual para la combinación del método de ensayo (RILEM), consistencia (plástica), especie (hookedend) y camino (colado en peine), cuando se hace la comparación por asociación cuádruple.

Palabras clave: Índice de refuerzo, resistencia residual, análisis de varianza.

\footnotetext{
1 Instituto Federal de Educação. Ciência e Tecnologia do Pará. Campus Belém. Pará. Brasil. CEP: 66093-020.

E-mail: marco.barbosa@ifpa.edu.br; rodrigo.totalmix@gmail.com

2 Universidade Federal do Pará. Pará. Brasil. CEP: 66075-110.

E-mail: marcelosp@ufpa.br; denio@ufpa.br; ramosedson@gmail.com

3 Universidade da Amazônia. Pará. Brasil. CEP: 66065-205. E-mail: mspmike@ hotmail.com

* Corresponding Author: marco.barbosa@ifpa.edu.br
} 


\section{INTRODUCTION}

The mechanical behavior of the steel fiber-reinforced concrete depends on the concrete matrices and the steel fiber properties (geometry, length, shape, tensile strength, elasticlmodulus, effective volume, distribution and orientation) [1]. Some authors in previous studies report that the raising of the fiber volume improves the mechanical response from the resistant behavior after the peak load [2-9]. However, it is necessary the existence of an appropriate fiber dosage, in this context [10] verified that the volume incorporation of long steel fibers of $30 \mathrm{~kg} / \mathrm{m}^{3}(0.4 \%)$, in volumetric fraction) to the concrete provided improvements to the load and the flexural strength comparing to the reference concrete. Another studies indicate substantial mechanical response from the steel-fiber reinforced concrete at a fiber volume range from $20 \mathrm{~kg} / \mathrm{m}^{3}(0.26 \%$, in volumetric fraction) to $45 \mathrm{~kg} / \mathrm{m}^{3}(0.60 \%)$, in volumetric fraction) [11-13] reports that hooked end steel fibers and the straight ones correspond to $67 \%$ and $9 \%$, respectively, in terms of commercialization, they have the shape factor between 20.4 and 152 in which the shape factors between 45 and 63 are equivalent to $50 \%$ of the commercialized fibers.

The post-peak behavior evaluation in the steel-fiber reinforced concrete occurs through an experimental flexural test [14]. The flexural test of the steel fiber reinforced concrete has some normative recommendations to the behavior evaluation, among them, International Union of Laboratories and Experts in Construction Materials, Systems and Structures [RILEM] with three-point tests. Another objective of this study is to evaluate the behavior of the dry-cast concrete produced with materials from Belem do Pará and with steel fibers randomly oriented (loose or cast), with factor shapes (65 or 80), theoretical volume $(0.25 \%$ or $0.38 \%$ or $0.50 \%)$ and reinforcing index (16.25 or 26.0 or 32.5$)$ and (20.0 or 32.0 or 40.0 ), respectively, obtained from the product of the shape factor by the theoretical volume, when it is characterized by the flexure test, according International Union of Laboratories and Experts in Construction Materials. Systems and Structures [15]. The parameters utilized in this study are based on experimental campaigns from the literature about dry-mix concrete, for example [16-17].

\section{EXPERIMENTAL METHODOLOGY}

The developed experimental methodology seeks to obtain mechanical characterization from the steel fiber reinforced concrete executing the flexure test by International Union of Laboratories and Experts in Construction Materials. Systems and Structures [15] to get the flexure strengths in the limit of proportionality (LOP) ( $\mathrm{fct}_{\mathrm{L}}$ ), equivalents $\left(\mathrm{feq}_{, 1}\right.$ or $\mathrm{feq}_{, 3}$ ) and residuals ( $\mathrm{fr}_{, 1}$ or $\mathrm{fr}_{, 2}$ or $\mathrm{fr}_{, 3}$ or $\left.\mathrm{fr}_{, 4}\right)$.

\section{MATERIALS AND METHODS}

In the experimental procedure, there was a physical characterization. dosage and the quantity of prismatic specimens with dimensions of $150 \mathrm{~mm}$ x $150 \mathrm{~mm}$ x $550 \mathrm{~mm}$, the results are presented in the Tables 1, 2 and 3, respectively. This research uses a reinforcing index parameter, as shown in the Table 2, which corresponds to the product of the theoretical volume by the shape factor from the steel fiber, in order to approach in a more comprehensive

Table 1. Physical characterization of the materials.

\begin{tabular}{|l|l|c|c|c|c|c|}
\hline \multicolumn{1}{|c|}{ Materials } & \multicolumn{1}{|c|}{ Type } & $\begin{array}{c}\text { CMD } \\
(\mathbf{m m})\end{array}$ & $\begin{array}{c}\text { Modulus } \\
\text { of fineness }\end{array}$ & $\begin{array}{c}\text { UM } \\
\left(\mathbf{g} / \mathbf{c m}^{3}\right)\end{array}$ & $\begin{array}{c}\text { EM } \\
\left(\mathbf{g} / \mathbf{c m}^{3}\right)\end{array}$ & Test method \\
\hline Cement & CP II-Z -32 RS & & & - & 3.02 & $\begin{array}{c}\text { NBR NM 23 } \\
\text { (ABNT. 2001) }\end{array}$ \\
\hline Fine aggregate & Sand fine & 1.20 & 2.03 & 1.46 & 2.63 & $\begin{array}{c}\text { NBR NM 52 } \\
\text { (ABNT. 2009) }\end{array}$ \\
\hline Course aggregate & River of pebble & 12.5 & 4.93 & 1.56 & 2.53 & $\begin{array}{c}\text { NBR NM 53 } \\
\text { (ABNT. 2009) }\end{array}$ \\
\hline \multicolumn{2}{|c|}{ Test method } & $\begin{array}{l}\text { NBR NM 248 } \\
\text { (ABNT. 2003) }\end{array}$ & $\begin{array}{c}\text { NBR NM 248 } \\
\text { (ABNT. 2003) }\end{array}$ & $\begin{array}{c}\text { NBR NM 45 } \\
\text { (ABNT. 2006) }\end{array}$ & & \\
\hline
\end{tabular}

CMD - characteristic maximum diameter; UM - unit mass; EM - específic mass; e CMD - characteristic maximum diameter. 
Table 2. Concrete dosage and steel fibers properties.

\begin{tabular}{|c|c|c|c|c|c|c|}
\hline \multirow[b]{2}{*}{ C:S:P:w/c } & \multicolumn{6}{|c|}{ Steel fiber properties } \\
\hline & Form & $\begin{array}{c}\left(\mathrm{kg} / \mathbf{m}^{3}\right) \\
(\% \text { by volume }-\mathrm{Vf})\end{array}$ & $\begin{array}{l}\text { Length } \\
\text { - Lf } \\
(\mathrm{mm})\end{array}$ & $\begin{array}{c}\text { Diameter } \\
\text { - df } \\
(\mathbf{m m})\end{array}$ & $\begin{array}{l}\text { Form } \\
\text { factor } \\
\text { (Lf/df) }\end{array}$ & $\begin{array}{c}\text { Reinforcement } \\
\text { index } \\
(\mathbf{V f * L f} / \mathbf{d f})\end{array}$ \\
\hline 1:2.30:2.46:0.32 & Loose or glued & $\begin{array}{c}20 \text { or } 30 \text { or } 40 \\
(0.25 \text { or } 0.40 \text { or } 0.50)\end{array}$ & $(35$ or 60$)$ & $(0.54$ or 0.75$)$ & $(65$ or 80$)$ & \begin{tabular}{|c}
$(16.25$ or 26 or 32.5$)$ \\
or $(20$ or 32 or 40$)$
\end{tabular} \\
\hline
\end{tabular}

C - cement CP II Z - 32 RS; S - sand; P - pebble; e w/c - water/cement ratio.

Table 3. Experimental program.

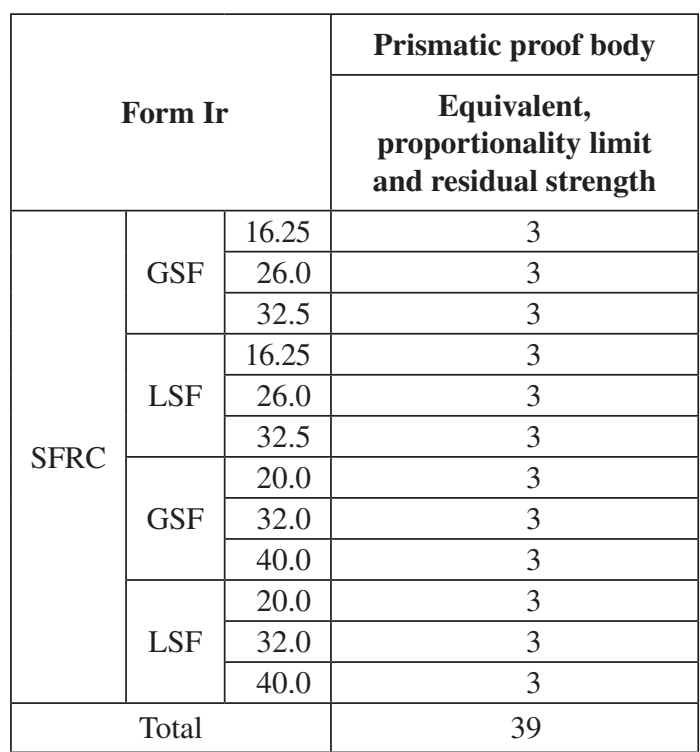

SRFC - steel fiber reinforced concrete; GSF - glued steel fiber; LSF - loose steel fiber.

way the interrelationships between the properties of the steel fibers, since reinforcement indices with close values for different theoretical volumes and form factors. The prismatic specimens were molded, densified and cured according recommendations from International Union of Laboratories and Experts in Construction Materials, Systems and Structures [15]. Another peculiarity of this research is related to the densifying methodology used in the reinforced concrete, which we first densified manually with 75 strokes in a single layer, and later we executed a mechanical densifying in a vibrating table. The cure process occurred by immersion in a water tank with saturated solution of calcium hydroxide for 28 days of age. We did the mechanical characterization performing the three-point flexure test in the prismatic concrete specimens of $150 \mathrm{~mm} \times 150 \mathrm{~mm} \times 550 \mathrm{~mm}$, according International Union of Laboratories and Experts in Construction Materials, Systems and Structures [15]. The displacement control occurred by means of a LVDT (Linear Variable Displacement Transducer), which was supported on a "yoke" device. We present the schematic representation of the assay by International Union of Laboratories and Experts in Construction Materials, Systems and Structures [15], in Figure 1. Aiming to do a better evaluation of the steel-fiber reinforced concrete there was a database consolidation presented in Table 4, which comprehends 34 three-point flexural experimental tests, according International Union of Laboratories and Experts in Construction Materials, Systems and Structures [15] and European Standards [18] with steel fiber properties: consistency (plastic or hard), type [hooked or straight], form [glued or loose], reinforcing index (13 or 65.1), behavior (slipsoftening or slip-hardening). It should be noted that there was a certain limitation for the consolidation of a steel-reinforced dry concrete database, since in the literature there are more studies with plastic consistency concrete with steel fibers in counterpart to the concrete of dry consistency facing to precast

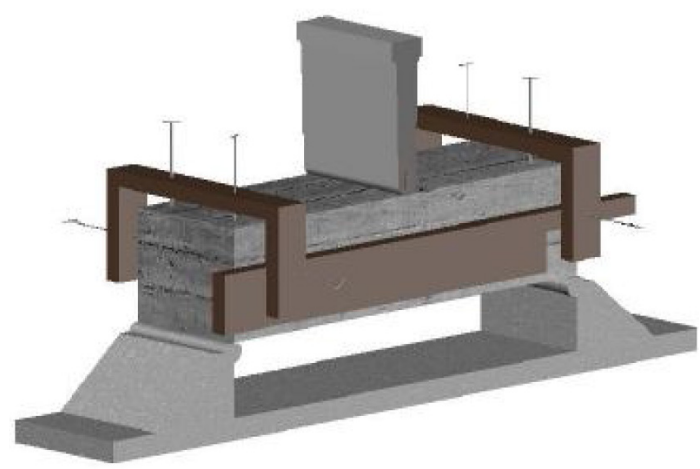

Figure 1. Schematic of the three-point bending test. 
Table 4. Authors' references for flexural strength without limit of proportionality, equivalent and residual (BD).

\begin{tabular}{|c|c|c|c|c|c|c|c|c|c|c|c|c|c|}
\hline \multirow{2}{*}{ Author } & \multirow{2}{*}{ Method } & & \multicolumn{11}{|c|}{ Properties steel fiber } \\
\hline & & $\mathrm{C}$ & $T$ & $\mathbf{F}$ & IR & fet.L & $\mathrm{feq}_{.2}$ & $\mathrm{feq}_{.3}$ & $\mathrm{fr}_{.1}$ & $\mathrm{fr}_{.2}$ & $\mathrm{fr}_{3}$ & $\mathrm{fr}_{.4}$ & Behavior \\
\hline \multirow{3}{*}{ [19] } & \multirow{3}{*}{$\mathrm{RM}$} & \multirow{3}{*}{$\mathrm{P}$} & \multirow{3}{*}{$\mathrm{H}$} & \multirow{3}{*}{ G } & 26 & 6.70 & 4.86 & 4.54 & 5.10 & - & - & 3.46 & \multirow{3}{*}{ SS } \\
\hline & & & & & 39 & 6.37 & 6.71 & 7.27 & 6.88 & - & - & 6.83 & \\
\hline & & & & & 52 & 6.90 & 9.85 & 9.06 & 9.95 & - & - & 6.63 & \\
\hline \multirow{9}{*}{ [20] } & \multirow{9}{*}{$\mathrm{RM}$} & \multirow{9}{*}{$\mathrm{P}$} & \multirow{9}{*}{$\mathrm{H}$} & \multirow{9}{*}{$\mathrm{G}$} & 19.1 & 3.54 & 2.68 & 2.63 & 2.74 & 2.69 & 2.56 & 2.36 & \multirow{3}{*}{ SS } \\
\hline & & & & & 27.9 & 3.56 & 2.97 & 2.99 & 2.99 & 3.02 & 2.99 & 2.85 & \\
\hline & & & & & 41.4 & 4.03 & 4.75 & 4.54 & 4.65 & 4.55 & 4.37 & 4.12 & \\
\hline & & & & & 18.75 & 4.73 & 3.47 & 3.52 & 3.61 & 3.57 & 3.50 & 3.31 & \multirow{3}{*}{$\mathrm{SH}$} \\
\hline & & & & & 40.7 & 4.61 & 4.80 & 5.13 & 4.85 & 5.24 & 5.23 & 5.12 & \\
\hline & & & & & 65.1 & 5.20 & 8.83 & 9.35 & 8.70 & 9.79 & 9.27 & 8.50 & \\
\hline & & & & & 25.4 & 4.58 & 3.48 & 3.68 & 3.62 & 3.84 & 3.67 & 3.41 & SS \\
\hline & & & & & 52.45 & 5.12 & 7.84 & 9.05 & 7.78 & 9.71 & 9.14 & 8.48 & $\mathrm{SH}$ \\
\hline & & & & & 63.4 & 5.89 & 10.78 & 11.35 & 10.69 & 12.1 & 11.03 & 9.98 & SS \\
\hline \multirow{3}{*}{ [21] } & \multirow{3}{*}{$\mathrm{RM}$} & \multirow{3}{*}{$\mathrm{P}$} & \multirow{3}{*}{$\mathrm{H}$} & \multirow{3}{*}{ G } & 20.9 & 7.20 & - & - & 3.14 & 2.52 & 1.80 & 1.47 & \multirow{3}{*}{ SS } \\
\hline & & & & & 41.9 & 7.65 & - & - & 7.51 & 6.94 & 6.14 & 5.10 & \\
\hline & & & & & 62.8 & 6.25 & - & - & 7.00 & 6.73 & 5.27 & 4.36 & \\
\hline \multirow{4}{*}{ [22] } & & & & & 16 & 3.84 & & & 2.55 & 2.44 & 2.22 & 1.99 & \\
\hline & FN & $\mathrm{P}$ & $H$ & $C$ & 20 & 3.62 & & & 4.10 & 4.18 & 3.94 & 3.49 & \\
\hline & EIN & $P$ & $\mathrm{H}$ & $G$ & 32 & 3.35 & & & 2.96 & 3.16 & 3.23 & 3.10 & SS \\
\hline & & & & & 40 & 3.12 & & & 3.93 & 4.49 & 4.56 & 4.62 & \\
\hline & & & & & 18.75 & - & 3.38 & 2.77 & 3.60 & 3.04 & 2.21 & 1.69 & \\
\hline & & & $\mathrm{H}$ & $\mathrm{L}$ & 37.5 & - & 5.61 & 5.21 & 5.59 & 5.77 & 4.22 & 3.42 & \\
\hline [23] & PM & $\mathrm{P}$ & & & 56.25 & - & 8.21 & 6.91 & 8.16 & 7.32 & 5.73 & 4.38 & CS \\
\hline [23] & KIM & $P$ & & & 15.6 & - & 1.72 & 1.25 & 1.99 & 1.29 & 0.89 & 0.66 & SS \\
\hline & & & $\mathrm{S}$ & $\mathrm{L}$ & 31.25 & - & 2.99 & 2.25 & 3.21 & 2.31 & 1.70 & 1.24 & \\
\hline & & & & & 46.8 & - & 4.62 & 2.85 & 4.75 & 3.04 & 1.49 & 1.19 & \\
\hline & & & & & 13 & 7.53 & - & - & 3.04 & 3.78 & 4.11 & 4.03 & \\
\hline [24] & EN & $\mathrm{P}$ & $\mathrm{H}$ & G & 26 & 7.42 & - & - & 6.21 & 8.21 & 8.36 & 7.76 & $\mathrm{SH}$ \\
\hline & & & & & 43.3 & 7.83 & - & - & 11.15 & 12.8 & 10.5 & 9.99 & \\
\hline [25] & EN & $\mathrm{D}$ & $\mathrm{H}$ & $\mathrm{G}$ & 26.8 & - & - & - & 4.63 & 4.56 & 4.27 & 3.83 & SS \\
\hline [26] & EN & $\mathrm{P}$ & $\mathrm{H}$ & $\mathrm{G}$ & 32.5 & - & - & - & 5.0 & 4.4 & 3.81 & - & SS \\
\hline & & & & & 33.7 & 5.2 & - & - & 3.2 & - & 2.4 & - & \\
\hline [27] & EN & $P$ & $\mathrm{H}$ & G & 48.4 & 5.8 & - & - & 5.1 & - & 3.9 & - & SS \\
\hline & & & & & 65 & 5.5 & - & - & 4.8 & - & 4.3 & - & \\
\hline$[28]$ & EN & $P$ & $\mathrm{H}$ & $\mathrm{G}$ & 53.4 & 4.21 & - & - & 3.31 & - & 3.5 & - & SS \\
\hline
\end{tabular}

concrete, and also of studies for characterization from residual resistances, that in this way influenced the obtaining of more recent literature. We performed an analysis of variance (ANOVA) to verify whether or not there is a meaningful statistical difference between the medium results of residuals strength $\left(\mathrm{fr}_{1}\right.$ or $\left.\mathrm{fr},{ }_{3}\right)$, when they were compared individually or in four-way analysis, in which the variables are: (i) Test method; (ii) Consistency; (iii) Shape; (iv) State. When the statistical differences were found we used Tukey or Fisher Test to verify the effect from the variable categories: Test method, Consistency, Shape and State. It was adopted a trust level equals to $95 \%$ and statistical significance of $5 \%(\alpha=0.05)$ to all the performed tests.

\section{RESULTS AND DISCUSSION}

In a qualitative way, we verified that energy from an efficient vibration and a methodology combined of 
manual and mechanical densifying process provided a satisfactory composite compaction, which provided a smooth surface and the elimination of voids by trapped air in the prismatic concrete specimens of steel-fiber reinforced concrete. This condition caused less porosity, considering we observed a little bubble formation when they were immersed in water for curing. In the mechanical characterization, obtained results for flexure strength in the limits of proportionality, equivalent and residual. The results are presented in Table 5 and shown in the Figures from 2 to 5 as the average results of load versus displacement of the glued steel fibers $(16.25$ or 26 or 32.5 ) and (26 or 32 or 40) obtained in the flexural test by International Union of Laboratories and Experts in Construction Materials, Systems and Structures [15].
From the Table 5 and Figures 2 to 5 regarding the residual resistances from the steel-fiber reinforced specimens with reinforcing indexes ( 16.25 or 26 or 32.5 ) and (26 or 32 or 40 ) we observed that the glued fibers had a better performance than the ones that were loose, because greater residual strength. And in some specimens containing steel fibers with reinforcing indexes (16.25 or 26 or 32.5$)$ and (26 or 32 or 40) in the glued and loose way presented a behavior where the residual strength $\left(\mathrm{fr}_{, 1}\right)$ had greater results regarding $\left(\mathrm{fr}_{3}\right)$, for example, SFRC-GSF-IR ( 16.25 or 26 or 32.5$)$ with theoretical volumes of $0.25 \%, 0.38 \%$ and $0.50 \%$, according to Table 5 . This behavior in the post-cracking phase is denominated as slip-softening, which was observed by [20-23, 25, 26-28]. According to [29], the steel fibers regularly present a slip-softening behavior due to the fact that

Table 5. The results of flexural strength in the limit of proportionality, equivalent and residual.

\begin{tabular}{|c|c|c|c|c|c|c|c|c|c|c|c|}
\hline & Form & IR & $\underset{(\mathbf{k N})}{\mathbf{F}_{\mathbf{L}}}$ & $\begin{array}{l}\text { fct. }_{. L} \\
(\mathbf{M P a})\end{array}$ & $\begin{array}{l}\text { feq. } 2 \\
\text { (MPa) }\end{array}$ & $\begin{array}{l}\text { feq. } 3 \\
(\mathrm{MPa})\end{array}$ & $\begin{array}{c}\mathbf{f r}_{.1} \\
(\mathbf{M P a})\end{array}$ & $\begin{array}{c}\mathbf{f r}_{.2} \\
(\mathbf{M P a})\end{array}$ & $\begin{array}{c}\mathbf{f r}_{.3} \\
(\mathbf{M P a})\end{array}$ & $\begin{array}{c}\mathbf{f r}_{.4} \\
(\mathbf{M P a})\end{array}$ & Behavior \\
\hline \multirow{12}{*}{ SFRC } & \multirow{3}{*}{ GSF } & 16.25 & 8.5 & 2.72 & 1.40 & 1.23 & 1.48 & 1.07 & 0.81 & 0.69 & \multirow{3}{*}{ Slip-softening } \\
\hline & & 26.0 & 9.88 & 3.16 & 2.02 & 2.31 & 2.33 & 2.54 & 2.18 & 2.00 & \\
\hline & & 32.5 & 8.88 & 2.84 & 2.34 & 2.28 & 2.45 & 2.34 & 2.04 & 2.08 & \\
\hline & \multirow{3}{*}{ LSF } & 16.25 & 10.72 & 3.43 & 1.54 & 2.27 & 1.87 & 2.00 & 2.01 & 2.01 & \multirow[b]{2}{*}{ Slip-softening } \\
\hline & & 26.0 & 10.35 & 3.31 & 5.02 & 4.40 & 2.56 & 2.61 & 2.25 & 2.17 & \\
\hline & & 32.5 & 10.62 & 3.40 & 3.27 & 4.04 & 3.11 & 3.69 & 3.98 & 3.90 & Slip-hardening \\
\hline & \multirow{3}{*}{ GSF } & 20.0 & 11.70 & 3.74 & 2.71 & 2.10 & 2.00 & 2.64 & 2.35 & 2.13 & \multirow{2}{*}{ Slip-softening } \\
\hline & & 32.0 & 10.46 & 3.35 & 2.40 & 2.42 & 4.07 & 4.24 & 4.09 & 3.74 & \\
\hline & & 40.0 & 10.00 & 3.20 & 2.85 & 3.62 & 3.41 & 4.19 & 4.41 & 4.18 & Slip-hardening \\
\hline & \multirow{3}{*}{ LSF } & 20.0 & 12.90 & 4.13 & 3.89 & 3.99 & 4.22 & 4.22 & 3.68 & 3.62 & Slip-softening \\
\hline & & 32.0 & 8.94 & 2.86 & 2.35 & 3.22 & 2.61 & 3.27 & 3.66 & 3.73 & \multirow{2}{*}{ Slip-hardening } \\
\hline & & 40.0 & 10.26 & 3.28 & 2.50 & 3.50 & 2.71 & 3.51 & 4.10 & 4.13 & \\
\hline
\end{tabular}

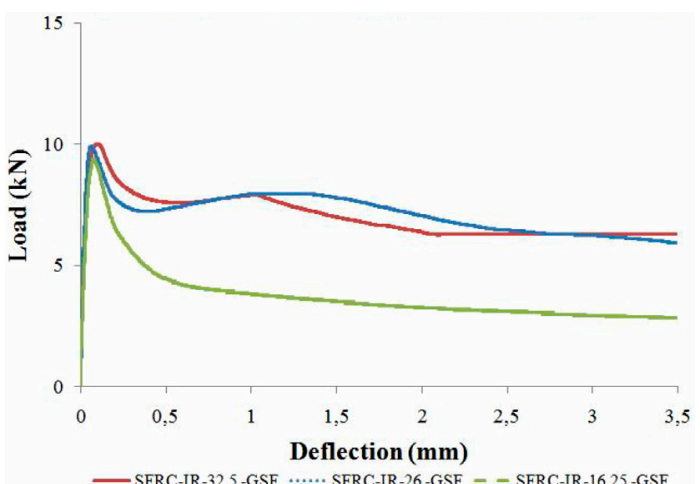

Figure 2. Load versus displacement for SFRCIR-(16.25 or 26 or 32.5) in the glued.

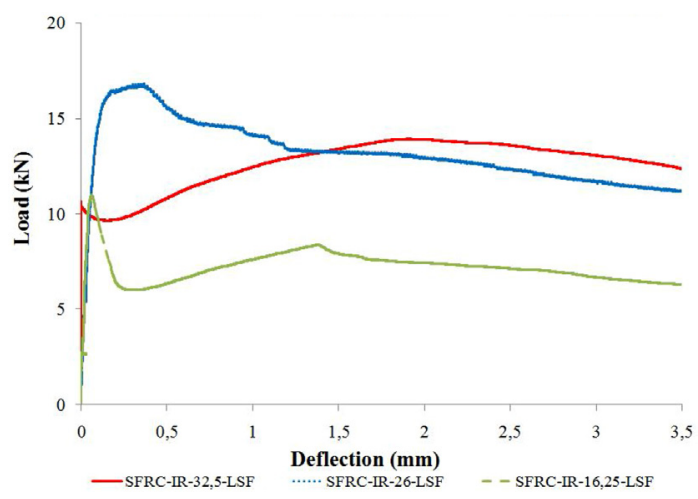

Figure 3. Load versus displacement for SFRCIR-(16.25 or 26 or 32.5) in the loose. 


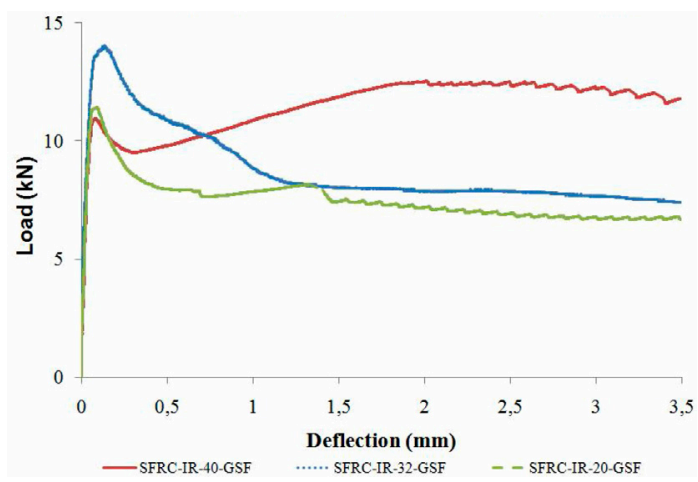

Figure 4. Load versus displacement for SFRC-IR-(26 or 32 or 40) in glued.

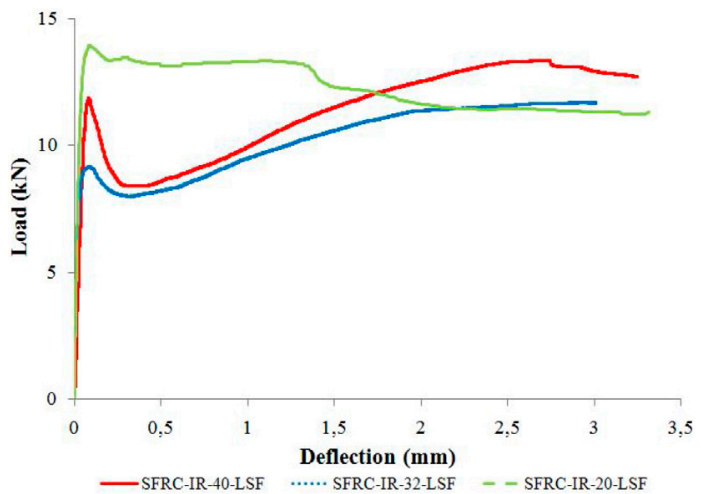

Figure 5. Load versus displacement for SFRCIR-(26 or 32 or 40$)$ in the loose.

the breaking of the fiber-matrix interaction occurs by friction in the tension transfer from the matrix to the fiber. According to [30], this can happen by virtue of the fiber's high elastic modulus and the low damage degree from the fiber in the matrix, allowing the fiber to become intensely anchored, what guarantee higher residual strength in levels of minor displacements. We observed in the prismatic specimen that the propagation of the crack aperture was complicated by the steel fibers GSF or LSF reinforcing index (26 or 32 or 40), which resisted until the occurrence of their disruption. While in the prismatic specimens with steel fibers with GSF or LSF reinforcement index (16.25 or 26 or $32.5)$ there was a slip during crack opening. When prismatic specimens are submitted to higher levels of displacements there is a greater level of fiber slip and its pullout resistance is conditioned to the concrete matrix integrity, where there may be faults in the fiber-matrix interface anchor region. These failures can occur by matrix's micro fissures in the regions around the fibers as there is an interception of the crack propagation in the matrix by the fibers [30]. However, a slip-hardening behavior was observed for the specimens at the theoretical volume of $0.50 \%$ for GSF-IR-40 and LSF-IR-32.5, as well as at the theoretical volumes of $0.38 \%$ and $0.50 \%$ for LSF40 , when residual strength $\left(\mathrm{fr}_{1}\right)$ was inferior to that achieved by $\left(\mathrm{fr}_{, 4}\right)$. This behavior was verified by [20-24], which may occur due to defibrillation in the fibers, which tends to increase the post-cracking resistant capacity as the displacement increases.

Through the analysis of variance (ANOVA) to the evaluation whether exists or no meaningful statistical difference among the mean values of residual strengths ( $\mathrm{fr}_{1}$ or $\mathrm{fr}_{3}$ ) when they are compared individually or in 4-way analysis of the variable categories, as example they were compared when the Test Method is RILEM (RM) and the Consistency is plastic (p) and the Shape is hooked end (HE) and the state is Glued (G) (RM-PHE-G). When the meaning differences are found in ANOVA, aiming more specific conclusions between the means, we applied the Tukey's and Fisher's test, which are presented in Tables 6 to 9 .

It was verified there was no meaningful statistical difference among the medium results of residual strength when individually compared to the categories of variables: Test Method ( $\mathrm{p}=0.223)$, Consistency $(p=0.818)$, Shape $(p=0.164)$ and State $(p=0.484)$, as presented in Table 6 . Similarly, there wasn't meaningful statistical difference, when compared the categories of variables: Test Method-Consistency-Shape-State $(\mathrm{p}=0.389)$ in four-way analysis, according Table 7. The residual strength $\left(\mathrm{fr}_{, 1}\right)$ has better results to the Test Method (RM), Consistency (plastic), Shape (hooked end) and State (glued), when compared individually such as in 4-way. This way, it was obtained higher results of residual strength $\left(\mathrm{fr}_{, 1}\right)$ with 4-way analysis to Test Method (RM) combined to Consistency (P), Shape (HE) and State (G) and Test Method (EN) combined to Consistency (D) and Shape (HE) and State $(\mathrm{G})$, according to Table 6 and 7 , with the residual strength $\left(\mathrm{fr}_{1}\right)$ being more expressive in the 4-way analysis for the category of variables (RM-P-HE-CP).

No meaningful statistical difference was verified among the mean values of residual strength $\left(\mathrm{fr}_{, 3}\right)$, 
Table 6. Resultant statistics from the ANOVA and Fisher test to evaluate the residual strength $\left(\mathrm{fr}_{1}\right)$, when they were individually compared in the variables categories: (i) Test Method; (ii) Consistency; (iii) Shape and (iv) State.

\begin{tabular}{|l|c|c|c|}
\hline \multicolumn{1}{|c|}{ Variable } & Category & Mean \pm Standard Deviation & p \\
\hline \multirow{2}{*}{ Test Method } & RM & $5.25 \pm 2.48 \mathrm{a}$ & \multirow{2}{*}{0.223} \\
\cline { 2 - 3 } & $\mathrm{EN}$ & $4.61 \pm 2.23 \mathrm{a}$ & \\
\hline \multirow{2}{*}{ Consistency } & $\mathrm{P}$ & $5.21 \pm 2.46 \mathrm{a}$ & \multirow{2}{*}{0.818} \\
\cline { 2 - 3 } & $\mathrm{D}$ & $4.63 \pm 0.00 \mathrm{a}$ & \multirow{2}{*}{0.164} \\
\hline \multirow{2}{*}{ Shape } & $\mathrm{HE}$ & $5.37 \pm 2.44 \mathrm{a}$ & \multirow{2}{*}{0.484} \\
\cline { 2 - 4 } & $\mathrm{S}$ & $3.32 \pm 1.38 \mathrm{a}$ & \\
\hline \multirow{2}{*}{ State } & $\mathrm{G}$ & $5.33 \pm 2.49 \mathrm{a}$ & \\
\cline { 2 - 4 } & $\mathrm{L}$ & $4.55 \pm 2.16 \mathrm{a}$ & \\
\hline
\end{tabular}

Note: Means followed by different letters in the column are different $(\mathrm{p}<0.05)$ by Fisher test.

RM - RILEM; EN - European Standard; P- plástic; D - dry; HE - hooked end; S - straigth; G - glued; L - loose.

Table 7. Resultant statistics from the ANOVA and Fisher test to evaluate the residual strength $\left(\mathrm{fr}_{, 1}\right)$, when they were compared by 4-way analysis in the variables categories: (i) Test Method; (ii) Consistency; (iii) Shape and (iv) State.

\begin{tabular}{|c|l|c|c|c|}
\hline \multirow{2}{*}{ Variable } & \multicolumn{1}{c|}{ Category } & \multicolumn{2}{c|}{$\begin{array}{c}\text { Mean } \pm \text { Standard } \\
\text { Deviation }\end{array}$} & p \\
\hline \multirow{5}{*}{ Test Method - Consistency - Shape- State } & RM-P-HE-G & $7.31 \pm 2.63$ & $\mathrm{a}$ & \\
\cline { 2 - 4 } & RM-P-HE-L & $5.78 \pm 2.29$ & $\mathrm{a}$ & \\
\cline { 2 - 4 } 0 & RM-P-HE-G & $5.61 \pm 2.63$ & $\mathrm{a}$ & \multirow{3}{*}{0.389} \\
\cline { 2 - 4 } & EN-D-HE-G & $4.63 \pm 0.00$ & $\mathrm{a}$ & $\mathrm{a}$ \\
\cline { 2 - 4 } & EN-P-HE-G & $4.61 \pm 2.33$ & $\mathrm{a}$ & \\
\cline { 2 - 4 } & RM-P-S-L & $3.32 \pm 1.38$ & $\mathrm{a}$ & \\
\hline
\end{tabular}

Note: Means followed by different letters in the column are different $(\mathrm{p}<0.05)$ by Fisher test. RM - RILEM; EN - European Standard; P- plástic; D - dry; HE - hooked end; S - straigth; G - glued; $\mathrm{L}$ - loose.

when they were compared individually the categories of variables: Test Method $(p=0.972)$. Consistency $(\mathrm{p}=0.923)$ and Shape $(\mathrm{p}=0.025)$, as demonstrated in Table 8. Similarly, there wasn't meaningful statistical difference $(\mathrm{p}=0.212)$, when compared Test Method, Consistency and Shape $(\mathrm{p}=0.025)$ in four-way analysis, as shown in Table 9. Higher values of residual strength were acquired $\left(\mathrm{fr}_{3}\right)$ to Test Method (EN), Consistency (dry), Shape (hooked end) when they were individually compared. From the analysis of the variances, the residual strength $\left(\mathrm{fr}_{3}\right)$ is statically the same, when combined the categories of variables: (i) Test Method (RM) and Consistency (P) and Shape (HE) and State (G) and (ii) Test Method (EN) and Consistency (P) and Shape (HE) and state $(\mathrm{G})$. In this stage there is a stress transfer process in the matrix-fiber interaction with the steel fiber working as a tool to realize the tension transfer [29]. There is a transfer of friction in the fiber-matrix interaction region, when there is the beginning of the steel fiber displacement process in the matrix [31].

\section{CONCLUSIONS}

In the experimental study with materials from the Metropolitan Region of Belém showed that the methodology combined of manual densifying and the 
Table 8. Resultant statistics from the ANOVA and Fisher test to evaluate the residual strength $\left(\mathrm{fr}_{3}\right.$ ), when they were compared individually in the variables categories: (i) Test Method; (ii) Consistency; (iii) Shape.

\begin{tabular}{|c|c|c|c|}
\hline Variable & Category & Mean \pm Standard Deviation & $\mathbf{p}$ \\
\hline \multirow{2}{*}{ Test Method } & EN & $4.55 \pm 2.32 \mathrm{a}$ & \multirow{2}{*}{0.972} \\
\hline & $\mathrm{RM}$ & $4.51 \pm 2.90 \mathrm{a}$ & \\
\hline \multirow{2}{*}{ Consistency } & $\mathrm{D}$ & $4.54 \pm 2.67 \mathrm{a}$ & \multirow{2}{*}{0.923} \\
\hline & $\mathrm{P}$ & $4.27 \pm 0.00 \mathrm{a}$ & \\
\hline \multirow{2}{*}{ Shape } & $\mathrm{HE}$ & $4.87 \pm 2.53 \mathrm{a}$ & \multirow{2}{*}{0.025} \\
\hline & $\mathrm{S}$ & $1.36 \pm 0.42 \mathrm{a}$ & \\
\hline
\end{tabular}

Note: Means followed by different letters in the column are different $(\mathrm{p}<0.05)$ by Fisher test.

RM - RILEM; EN - European Standard; P- plástic; D - dry; HE - hooked end; S - straigth; G - glued; L - loose.

Table 9. Resultant statistics from the ANOVA and Fisher test to evaluate the residual strength $\left(\mathrm{fr}_{3}\right)$, when they were compared by 4-way analysis in the variables categories: (i) Test Method; (ii) Consistency; (iii) Shape and (iv) State.

\begin{tabular}{|c|l|c|c|}
\hline \multicolumn{1}{|c|}{ Variable } & Category & Mean \pm Standard Deviation & p \\
\hline \multirow{4}{*}{ Test Method - Consistency - Shape - State } & RM-P-HE-G & $5.41 \pm 2.95 \mathrm{a}^{*}$ & \\
\cline { 2 - 3 } & EN-P-HE-G & $4.57 \pm 2.42 \mathrm{a}^{*}$ & \multirow{4}{*}{0.212} \\
\cline { 2 - 3 } & EN-D-HE-G & $4.27 \pm 0.00 \mathrm{a}^{*}$ & \\
\cline { 2 - 3 } & RM-P-HE-L & $4.05 \pm 1.77 \mathrm{a}^{*}$ & \\
\cline { 2 - 3 } & RM-P-S-L & $1.36 \pm 0.42 \mathrm{~b}^{*}$ & \\
\hline
\end{tabular}

Note: Means followed by different letters in the column are different $(\mathrm{p}<0.05)$ by Fisher test.

RM - RILEM; EN - European Standard; P- plástic; D - dry; HE - hooked end; S - straigth; G - glued; L - loose.

mechanism used in this research regarding the reinforced concrete resulted in a smooth surface appearance and, in a qualitative way, allowed the reduction of trapped air voids, influencing the porosity reduction.

And although there were better results from residual strengths of specimens reinforced with steel fibers in the loose way comparing to the ones glued. It can be observed that the load versus displacement of the flexural tests indicate slip-softening behavior in the theoretical volume $(0.25 \%$ and $0.38 \%$ and $0.50 \%$ ) for glued steel fiber with reinforcing index (16.25 and 26 and 32.5), and slip-hardening at the theoretical volume $0.50 \%$ for the glued steel-fiber with a reinforcing index equals to 40 , and theoretical volume $(0.38 \%$ and $0.50 \%)$ for steel fiber in the loose way with reinforcing index of (32.5 or 40). It was verified that there was crack propagation until rupture from the steel fibers with length of $60 \mathrm{~mm}$ in both loose and glued-types with reinforcing index
( 26 or 32 or 40). There was no breaking but sliding of the $35 \mathrm{~mm}$ length steel fibers in both loose and glued type with reinforcing indexes (16.25 or 26 or $32.5)$ during the opening of the cracks.

The analysis of variance of the database contributes to indicate that the residual forces $\left(\mathrm{fr}_{.}{ }_{1}\right.$ or $\mathrm{fr}_{.3}$ ) for the combination of Test Method (MR), Consistency (plastic), Shape (hooked end) and State ), when compared individually or by 4-way analysis, except for $\mathrm{fr}_{3}$, when compared to the State category individually and specifically for RM-P-S-L.

\section{REFERENCES}

[1] N. Buratti, N.C. Mazzottiand and M. Savoia. "Post-cracking behaviour of steel and macro-synthetic fibre-reinforced concretes". Construction and Building Materials. Vol. 25, Issue 5, pp. 2713-2722. 2011. ISSN: 0950-0618. 
[2] M.T. Kazemi, F. Fazilehand and M.A. Ebrahiminezhad. "Cohesive crack model and fracture energy of steel-fiber-reinforcedconcrete notched cylindrical specimens". Journal Materials in Civil Engineering ASCE. Vol. 19. Issue 10, pp. 884-890. 2007. ISSN: 1943-5533.

[3] A.E. Naaman. "High performance fiber reinforced cement composites: classification and applications". In: CBM-CI International Workshop; Karachi. Pakistan, pp. 389-401. 2007.

[4] G. Giaccio, J.M. Tobes and R. Zerbino. "Use of small beams to obtain design parameters of fibre reinforced concrete". Cement Concrete Composites. Vol. 30, Issue 4, pp. 297-306. 2008. ISSN: 0958-9465.

[5] A.M. Brandt. "Fibre reinforced cementbased (FRC) composites after over 40 years of development in building and civil engineering". Composite Structures. Vol. 86, Issue 1-3, pp. 3-9. 2008. ISSN: 0263-8223.

[6] N.M. Long and R. Marian. "Investigation of fracture properties of steel fiber reinforced concrete". In: Proceeding of the 3rd ACF International Conference. ACF/VCA, pp. 854-861. 2008.

[7] M. di Prisco, G. Plizzari and L. Vandewalle. "Fibre reinforced concrete: New design perspectives". RILEM Materials and Structures. Vol. 42, Issue 9, pp. 1261-1281. 2009. ISSN: 1871-6873.

[8] J. Walraven. "High performance fiber reinforced concrete: progress in knowledge and design codes". RILEM Materials Structures. Vol. 42, Issue 9, pp. 1247-1260. 2009. ISSN: 1871-6873.

[9] F. Bencardino L. Rizzuti G. Spadea and R.N. Swamy. "Experimental evaluation offiber reinforced concrete fractureproperties". Composites Part B: Engineering. Vol. 41, Issue 1, pp. 17-24. 2010.

[10] F. Altun, T. Haktanir and K. Ari. "Effects of steel fiber addition on mechanical properties of concrete and RC beams". Construction and Building Materials. Vol. 21, Issue 3, pp. 654-661. 2007. ISSN: 1359-8368.

[11] F. Papworth. "Design guidelines for the use of fiber reinforced shotcrete in ground support". Research Report. Shotcrete Spring, pp. 16-21. 2002.
[12] P. Ganesh and Chaudhary. "SFRC for industrial floors". NBMCW. Research Report. Mumbai: Bekaert. Industries PVT Ltd. 2009.

[13] J. Katzer and J. Domski. "Quality and mechanical properties of engineered steel fibres used as reinforcement for concrete". Construction and Building Materials. Vol. 34, pp. 243-248. 2012. ISSN: 0950-0618.

[14] M. di Prisco, G. Plizzari and L. Vandewalle. "Fiber reinforced concrete in the new FIB model code". In: Proceedings of the 3rd fib International Congress; Gaylord National Resort near Washington. D.C. 2010.

[15] Final Recommendation [RILEM TC 162TDF]. "Test and design method for steel fiber reinforced concrete $-\sigma-\varepsilon$ design method". 2003.

[16] R. Monte, G.S. Toaldo, and A.D. Figueiredo. "Avaliação da tenacidade de concretos reforçados com fibras através de ensaios com sistema aberto". Revista Matéria. Vol. 19, Issue 2, pp. 132- 149. 2014. ISSN: 1517-7076.

[17] European Standard [EN 14651]. Test method for metallic fibre concrete - measuring the flexural tensile strength (limit of proportionality (LOP), residual). Brussels. BE: European Committee for Standardization. 2007.

[18] J. Barros and J. Antunes. "Experimental characterization of the flexural behaviour of steel fibre reinforced concrete according to RILEM TC 162-TDF recommendations". In: International RILEM Workshop on Test and Design Methods for Steel fibre Reinforced Concrete. Vol. 18, pp. 77-89. 2003.

[19] J. Barros, A. Ribeiro, V. Cunha and A. Antunes. "Fibras de aço no reforço ao corte de vigas de betão armado". Dimensionamento de estruturas de betão reforçado com fibras de aço. DEC-UM. Portugal. 2003.

[20] L.A.P. Lourenço. "Betão Reforçado com Fibras: aplicações e técnicas de inspeção e reforço de elementos estruturais afetados pela ação de um fogo". [Doutoramento]. Braga. Portugal: Universidade do Minho. Escola de Engenharia. 2012.

[21] R.P.A.F.P. Lima. "Utilização de fibras metálicas com funções estruturais em estruturas de betão". [Dissertação]. Porto. Portugal: Departamento de Engenharia Civil. 
Faculdade de Engenharia da Universidade do Porto. 2012.

[22] P. Pujadas, A. Blanco, A. de la Fuente and A. Aguado. "Cracking behavior of FRC slabs with traditional reinforcement". Materials and Structures. Vol. 45, Issue 5, pp. 707-725. 2012. ISSN: 1871-6873.

[23] M. Pajak and T. Ponikiewski. "Flexural behavior of self-compacting concrete reinforced with different types of steel fibers". Construction and Building Materials. Vol. 47, pp. 397-408. 2013. ISSN: 0950-0618.

[24] J.G. Gomes. "Influência das fibras metálicas no comportamento ao esforço transverso de vigas SFRC". [Dissertação]. Porto. Portugal: Departamento de Engenharia Civil. Faculdade de Engenharia da Universidade do Porto. 2013.

[25] M.A. Arid. "Avaliação da medida de tenacidade do concreto reforçado com fibras de aço". Dissertação. Uberlândia. MG. Brasil: Programa de Pós-graduação em Engenharia Civil da Universidade de Minas Gerais. 2014.

[26] N. Görander and C. Halldén. "Crack Width Profiles for Fibre-reinforced Concrete
Elements with Conventional Reinforcement". Master of Science. Göteborg. Sweden: Chalmers University of Technology. 2015.

[27] L. Liao, A. de la Fuente, S. Cavalaro and A. Aguado. "Design procedure and experimental study on fibre reinforced concrete segmental rings for vertical shafts". Materials and Design. Vol. 92, pp. 590-601. 2016. ISSN: 0264-1275.

[28] M. Colombo, P. Martinelli and M. di Prisco. "On the evaluation of the structural redistribution factor in FRC design: a yield line approach". Materials and Structures. Vol. 50, Issue 1, pp. 3-18. 2017.

[29] A. Bentur and S. Mindess. "Fiber reinforced cementitious composites". Modern Concrete Technology Series. 2007.

[30] R.P. Salvador and A.D. Figueiredo. "Comparative evaluation of the mechanical behavior of synthetic and steel fiber-reinforced concrete". Revista Matéria. Vol. 18, Issue 2, pp. 1273-1285. 2013. ISSN: 1517-7076.

[31] P.N. Balaguru and S.P. Shah. "Fiber reinforced cement composites". New York. NY: McGrawHill. International Editions. 1992. 